\title{
Hatching success affects the timing of spawning by the intertidally spawning puffer Takifugu niphobles
}

\author{
Kazunori Yamahira* \\ Amakusa Marine Biological Laboratory, Kyushu University, Tomioka, Reihoku-cho, Amakusa, Kumamoto 863-25. Japan
}

\begin{abstract}
The puffer Takifugu niphobles, which is an intertidal spawner and deposits eggs in the upper intertıdal zone, spawns on several days of every spring tide during spring to summer (i.e. the semilunar spawning cycle). As the season progresses, however, the timing of spawning events progressively shuft from just before to just after the new or full moon. This study explains why there is the seasonal shift in the timing of spawning from the viewpoint of larval hatching success. Larval sampling in the field and rearing experiments in the laboratory indicated that hatching occurred only when the nighttime high tides flood the stranded eggs. According to ambient temperatures, incubation periods tended to be shorter as the season progressed. Therefore. spawning occurs prior to the peak sprang tides (dates of new and full moons) early in the season to allow sufficient time for completion of embryological development prior to the occurrence of neap tides, which may not flood the intertidal spawning site. The relationship between the zone of stranded eggs and the tidal regime at the site indicated that most of the completely developed embryos can be successfully submerged by nighttime high tides for the greater part of the season. Quadrat sampling of eggs showed that many embryos died because of temperature stress during intertidal incubation. The most advantageous time for embryo survival is, especially later in the season, after the peak spring tides when the intertidal zone is inundated at midday and temperatures are moderated by the water cover The progressive shift in the timing of spawning is the result of a seasonal trade-off between the embryo survival during intertidal incubation and successful hatching during periods of submergence.
\end{abstract}

KEY WORDS: Egg survival Incubation - Larvae Hatching success - Tides Timing of spawning Selinlunar Intertidal spawning

\section{INTRODUCTION}

The marine environment fluctuates physically on a variety of time scales but principally with the diurnal, tidal, lunar/semilunar, and seasonal cycles. These cycles affect many aspects of the life histories of marine organisms, and they often coordinate behavioral, physiological, and reproductive activity within species. That is, the linkages with these cycles ensure that hatching, feeding, movement, spawning activity, etc. can be accomplished at the most appropriate times of the day, month, or year (Korringa 1947, Barnwell 1976, Berry 1986, Christy 1986, Gibson 1992, Leatherland et al. 1992, Morgan 1995)

Semilunar spawning cycles occur commonly among fish species that produce benthic eggs (Thresher 1984). This tendency is assumed to be related to the timing

·E-mail: kayamsca@mbox.nc.kyushu-u.ac.jp of larval hatching: benthic eggs have considerably narrow diel hatching windows, and those windows coincide with tides that are appropriate for dispersal only during 2 short periods in each lunar month (Thresher 1984, Gladstone \& Westoby 1988). However, the hypothesis assumes that there are great interspecific similarities in the requirements and capabilities of the larvae. Thus, the hypothesis may be oversimplified and cannot account for a variety of lunar spawning patterns of many fish species (Robertson 1991). To explain the spawning pattern of a particular fish, other factors related to the biology and ecology of that species also must be considered.

The present study considers the case of the intertidal spawning puffer Takifugu niphobles (Pisces, Tetraodontidae). Spawning in this species is synchronized with the semilunar cycle and is restricted to several days around the new and full moon, i.e. spring tides 
(Uno 1955, Katayama et al. 1964, Nozaki et al. 1976 , Tsutsumi 1978, Suzuka \& Isogai 1979, Dotsu et al. 1990). The puffer spawns benthic eggs at the water's edge of the upper intertidal zone, and it has been reported that eggs are stranded under pebbles of the upper intertidal zone and incubated there (Yamahira 1996). The eggs are exposed to air for the greater part of the day, and it has also been reported that some of the stranded eggs died apparently because of high temperatures and desiccation during the periods of exposure (Yamahira 1996). Although the eggs are usually submerged twice daily during high tides, several days after being deposited in the intertidal zone they may not be inundated because the amplitudes of tidal fluctuation and high tide levels at the site decline progressively after each spring tide. Submergence and return to the sea are essential for the planktonic larval phase of the fish. Thus, it is expected that the puffer also has a much narrower diel hatching window: the stranded eggs must hatch while high tides reach them. However, the duration of incubation depends on ambient temperatures, which is expected to change during the long spawning season (May to August or September, Yamahira 1994). It remains to be seen whether the stranded eggs are actually submerged at the time of hatching and whether the larvae can hatch out successfully throughout the season.

Yamahira (1994) concluded that the timing of a day's spawning in the puffer is affected by the diumal and tidal cycles, and that the semilunar pattern of spawning days is caused by a temporal combination of both cycles; the puffer spawns on days when high tides are at dusk to early evening, i.e. on days around the new or full moon. As the spawning season progresses, however, the timing of spawning events progressively shifts from just before to just after the new or full moon, though the combination of the diurnal and tidal phases does not vary throughout the season

This study explains why there is a seasonal shift in the timing of Takifugu niphobles spawning relative to the lunar cycle from the viewpoint of larval. hatch. The number of hatching larvae is provided by 2 components: embryo survival during intertidal incubation and successful hatch during periods of submergence. I examined each separately throughout the season. The embryo survival during intertidal incubation is assessed by directly collecting eggs from the beach. To examine the successful hatch during periods of submergence, on the other hand, the following 3 aspects are necessary conditions to consider. (1) the timing of a day's hatch; (2) incubation periods of eggs in the field, and (3) tide levels where the eggs were stranded. These parameters are used to judge whether completely developed embryos can be successfully submerged by tides under the observed tidal regime at the site.

\section{MATERIALS AND METHODS}

Study site and materials. This study was carried out on a beach in the innermost part of Tomoe Cove, in the western coast of Kyushu Island, Japan $\left(32^{\circ} 32^{\prime} \mathrm{N}\right.$, $130^{\circ} 2^{\prime} \mathrm{E}$ ). The beach, which consists of pebbles (Yamahira 1997), is about $10 \mathrm{~m}$ wide, and spawning of Takifugu niphobles occurs only in this area. The amplitude of tidal fluctuation is about $3.2 \mathrm{~m}$ during spring tides. The coastline of this beach is composed of a concrett: wall, and the beach is exposed for a distance of $18 \mathrm{~m}$ seaward from the coastline (i.e. the concrete wall) during the mean low water of spring tide (MLWS).

Spawning of the puffer occurs at the water's edge during late rising tidal phases during dusk-early evering, and their gametes are released at the upper intertidal zone (Yamahira 1994, 1996, and references therein). The spawning season lasts from May to August or September, and the days on which the spawning occurs are restricted to those associated with spring tides, i.e. the semilunar spawning cycle (Yamahira 1994). In this paper, I call the spawning days around each new or full moon the 'spawning series' There were 7 and 9 spawning series, that included 30 and 26 spawning days, in 1992 and 1993, respectively (Fig 1). In both years, each spawning series started before the day of the new or full moon earlier in the season (May to June), but tended to start after the new or full moon later in the season (July to September)

Embryo survival during incubation. Earlier work conducted in 1992 shows that eggs of Takifugu niphobles are deposited and incubated under pebbles mainly within $5 \mathrm{~m}$ of the coastline (Yamahira 1996). Thus, to assess embryo survival during incubation, eggs were collected from this area once every spawning series (4 d after each series started) in 1993. At the center of the spawning area, five $5 \mathrm{~m}$-transect lines were extended offshore perpendicular to the coastline. The distance between each pair of adjacent transects was $1 \mathrm{~m}$. Along each of the 5 transect lines, five $10 \times$ $10 \mathrm{~cm}$ quadrats were set at $1 \mathrm{~m}$ intervals from 1 to $5 \mathrm{~m}$ from the coastline, that is, a total 25 quadrats were set in the area. Pebbles and gravel within each quadrat (about $10 \mathrm{~cm}$ in depth) were collected and brought back to the laboratory. After fixing in $10 \%$ neutralized formalin, eggs were sieved out by a $1.0 \mathrm{~mm}$ mesh net (mean egg diameter $\pm \mathrm{SD}=0.98 \pm 0.001 \mathrm{~mm}$; Uno 1955). Each egg was checked to determine whether it had been alive or dead at the time of collection, and the proportion of live eggs in each quadrat was calculated. Because live eggs were spherical and transparent, the embryo and its developmental stage could be seen through the egg membrane; dead eggs were white and opaque. Some eggs had been killed by desiccation and were collapsed. 
Days from the new or full moon
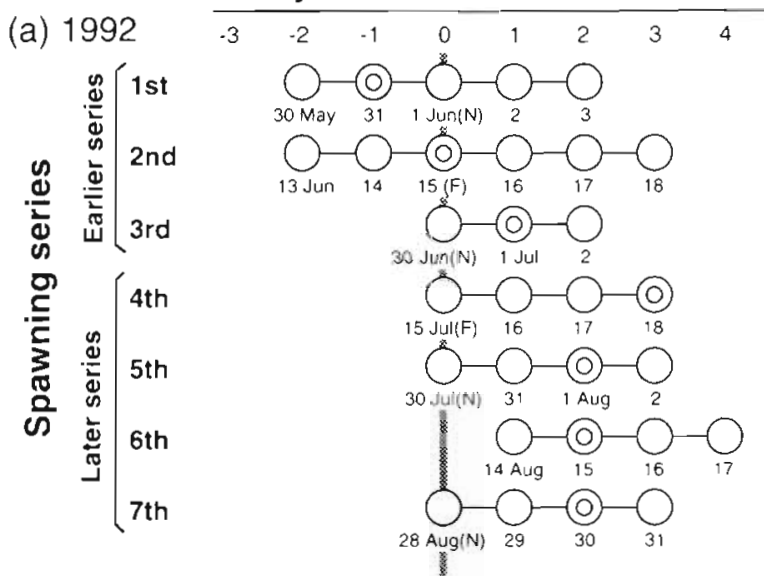

(b) 1993

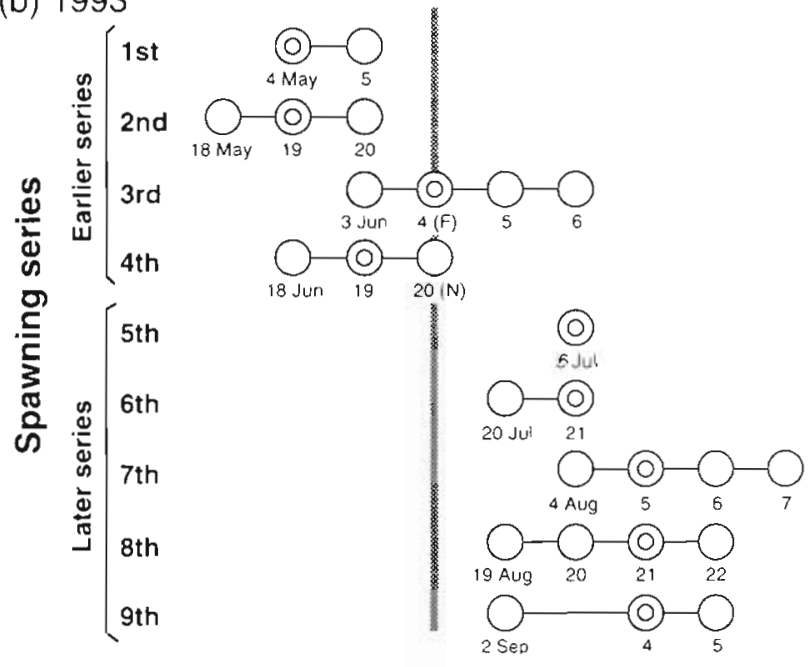

Fig. 1 Takifugu niphobles. Spawning days in relation to lunar days in (a) 1992 and (b) 1993. Circles indicate the days when spawning occurred. Double circles are the days when spawning occurred most frequently in each spawning series. F: full moon days; $N$ : new moon days; these are aligned along the shaded bar

The Kruskal-Wallis test was used to examine similarity or difference in the embryo survival among the spawning series and followed by the Scheffé method for multiple comparisons.

Timing of a day's hatch. To determine the time of day at which hatching occurred, newly hatched puffer larvae were collected from the beach at regular intervals, using a square hand net $12 \times 14.5 \mathrm{~cm}$ in size with a $0.05 \mathrm{~mm}$ mesh net. The mean size ( $\pm \mathrm{SD}$ ) of newly hatched larvae is $2.06 \pm 0.04 \mathrm{~mm}$ (Uno 1955). By slowly sweeping 10 times from side to side with an amplitude of $2 \mathrm{~m}$, a volume of $348 \mathrm{l}$ was filtered. The net was swept in the water column less than $50 \mathrm{~cm}$ under the water surface. This sampling was carried out every $2 \mathrm{~h}$ from 12:00 h on 27 August to 12:00 h on 28 August in 1994. At each time of sampling, larvae were collected at 3 points: 2, 9, and $16 \mathrm{~m}$ from the coastline. Sampling was carried out only at submerged locations. Number of replication at each location at each time was 5

To examine the effect of the diurnal cycle on the timing of hatching, eggs obtained by artificial fertilization were reared in $50 \mathrm{ml}$ beakers that were completely submerged in aerated seawater. Five beakers, each containing about 100 eggs, were incubated at both $24^{\circ} \mathrm{C}$ and $16^{\circ} \mathrm{C}\left( \pm 0.6^{\circ} \mathrm{C}\right.$ in range) Incubations at the 2 temperatures started immediately after fertilization; incubation at $24^{\circ} \mathrm{C}$ started at $18: 09 \mathrm{~h}$ on 4 June and that at $16^{\circ} \mathrm{C}$ started at $19: 25 \mathrm{~h}$ on 20 August in 1993 . The eggs were exposed to dim natural sunlight, in a cycle of light and darkness consistent with the natural diurnal cycle. Each beaker was inspected every $3 \mathrm{~h}$ to see whether newly hatched larvae were present. After hatching began, the numbers of newly hatched larvae wore counted every $2 \mathrm{~h}$ and removed. When no live embryos remained, the experiment was terminated.

Incubation period of eggs and field temperature. To estimate the incubation periods of the eggs in the field, artificially fertilized eggs were obtained and reared in the field. In 1993, a mature male and female were collected from the beach on the second day after each spawning series started, because spawning tended to occur most frequently on the second day (Fig. 1; and see also Yamahira 1994). They were brought back to the laboratory, and eggs were artificially fertilized. During the next nighttime or daytime low tide, the fertilized eggs were put at locations 2 to $3 \mathrm{~m}$ from the coastline $(240 \mathrm{~cm}$ above MLWS) using egg-containers with a mesh cap but no bottom (for details, see Yamahira 1996). About 10 containers had been buried in the substratum 2 or $3 \mathrm{~d}$ before the eggs were transferred to stabilize the substratum, and about 100 eggs were put into each container. The containers were capped and covered by pebbles to simulate natural conditions. Four days later the containers were recovered together with the gravel they contained. After fixing, the eggs were sieved out from the containers.

At the time of collection, the eggs were still developing. Thus, assuming the developmental rate of the eggs from fertilization to hatching was constant, the incubation period was estimated as follows:

$$
I P=P / T
$$

where IP is the estimated incubation period until hatching, $P$ is the period between the fertilization and collection of the eggs, and $T(0<T<1)$ is the relative developmental stage, in which the whole interval between fertilization and hatching is defined as 1 The relative developmental stage of an egg was determined by comparing it with eggs that were reared at $25^{\circ} \mathrm{C}$ in the laboratory and photographed at 16 developmental stages at equal intervals. 
During each transplantation, I went to the site almost evcry hour and recorded nest temperatures. When the site of transplantation was exposed, temperatures under pebbles were recorded using a digital thermometer. When the site was submerged, on the other hand, water temperatures were recorded. The mean temperature to which the transplanted eggs were subjected was calculated from all the temperatures measured during the course of the incubation.

Tide level of stranded eggs. When spawning was observed in 1993, times when each day's spawning started and ended were recorded, and the zone where the spawning occurred was estimated by converting the start and end times into the tidal heights $(\mathrm{cm})$ at each time, using the published tide table for the study site (Japan Meteorological Agency 1992) Since eggs are deposited only where spawning occurred (Yamahira 1996), the spawning zone of each day was regarded to be the zone of stranded eggs.

\section{RESULTS}

The seasonal shift in the timing of spawning relative to the lunar cycle was statistically proved: if the day of new or full moon is regarded as Day 0 (see Fig. 1), the spawning occurred on significantly earlier days in the earlier spawning series (mean $\pm \mathrm{SD}, 0.43 \pm 1.55, \mathrm{n}=14$, and $-0.83 \pm 1.40, n=12$, in 1992 and 1993, respectively) than in the later series $(1.75 \pm 1.24, \mathrm{n}=1.6$, and $2.64 \pm 1.28, \mathrm{n}=14$ ), both in 1992 and 1993 (MannWhitney $U$-test, $p<0.05$ for both years)

The quadrat samplings of eggs indicated that many embryos died during intertidal incubation (Fig. 2). Embryo survival differed significantly among the

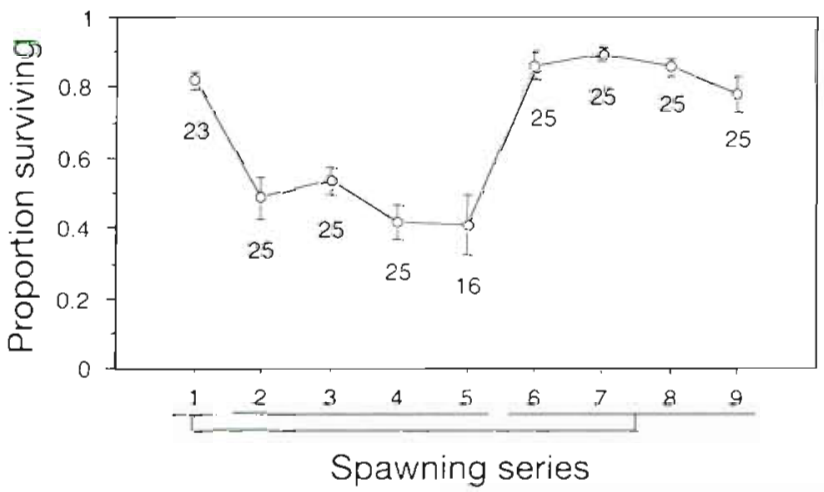

Fig. 2. Takifugu niphobles. Survival of eggs (mean proportion surviving \pm SE) collected in each spawning series in 1993. Numbers of samples on which the statistic is based are given for each series. Lines under the spawning series indicate that no significant ( $5 \%$ level) difference in the mean order of the survival was detected between any pairs of spawning series using the Scheffer method spawning series (Kruskal-Wallis test, $\mathrm{df}=8, \mathrm{p}<0.0001$ ). In particular, mean survival tended to be lower earlier in the season, except for the 1st series; about half of the strandnd eggs were dead at the time of collection. In contrast, mean survival was relatively higher later in the season; around $80 \%$ of the stranded eggs were still alive at the time of collection. Multiple comparisons indicated that the mean survivals earlier in the season except for the 1 st series were significantly lower than those of the remaining.

There were 2 high tides within the day on which puffer larvae were collected at the site, one during the day and one at night. Each high tide reached or nearly reached the coastline. Larvae were caught mainly in the upper intertidal zone ( $2 \mathrm{~m}$ from the coastline) during the nighttime high tide (Fig. 3). Over this period, average catches ranged from about 124 to 797 larvae $\mathrm{m}^{-3}$. Only a few larvae were caught in the lower zones ( 9 and $16 \mathrm{~m}$ ) during the night and in the upper zone during the daytime high tide. No or very few larvae were caught in the lower zone(s) while the upper intertidal zone was exposed

In the laboratory, the average percentage of artificially fertilized eggs that hatched out successfully was $92.1 \%$ at $24^{\circ} \mathrm{C}$ and $95.6 \%$ at $16^{\circ} \mathrm{C}$. The time from fertilization to the first hatching took $4 \mathrm{~d}$ at $24^{\circ} \mathrm{C}$ and $10 \mathrm{~d}$ at $16^{\circ} \mathrm{C}$. Even when reared under seawater all day, the eggs tended to hatch out during the dark (Fig. 4). Approximately 70 to $80 \%$ of the larvae hatched on the first night.

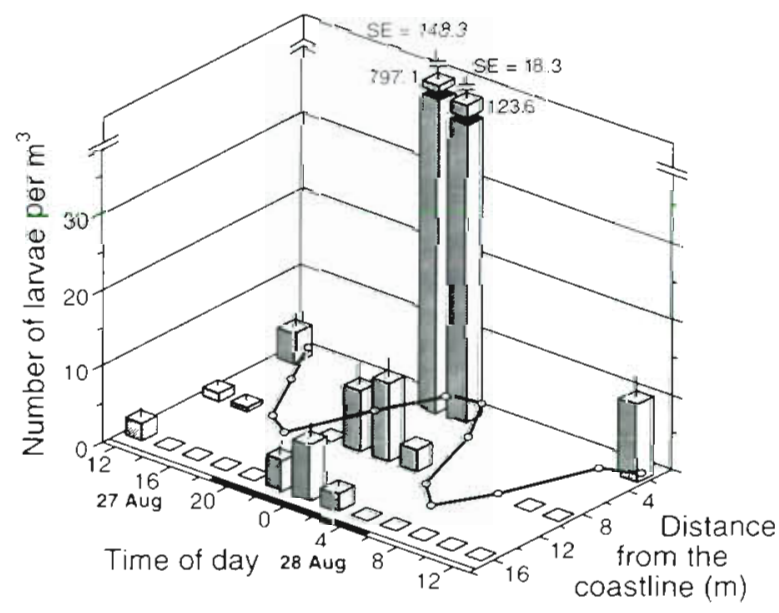

Fig. 3. Takifugu niphobles. Mean numbers of larvae per $\mathrm{m}^{3}$ $( \pm S E, n=5$ ) caught at 2,9 , and $16 \mathrm{~m}$ from the coastline every $2 \mathrm{~h}$ from $12: 00 \mathrm{~h}$ on 27 August to 12:00 h on 28 August in 1994 . Sampling was carried out only at locations that were submerged at the tume of sampling. The contınuous line shows the distance of the water's edge from the coastline at each time. Black and white bars along the $x$-axis indicate night and day, respectuvely 
Developmental speed of eggs in the field was almost uniform within a cohort, and no variation in the relative developmental stage $(T)$ was calculated from the comparison with the photographs of 16 developmental stages. Incubation periods of eggs in the site were estimated at 4 to $7 \mathrm{~d}$ (Table 1). However, the incubation periods tended to be shorter as the spawning season progressed. In the earlier (1st to 4th) spawning series (May to June), the incubation period was estimated at 5 to $7 \mathrm{~d}$. On the other hand, in the later (5th to 9th) series (July to September), it was estimated at less than $5 \mathrm{~d}$. The incubation periods were significantly longer in the earlier spawning series (mean incubation period $\pm \mathrm{SD}=6.34 \pm 0.76 \mathrm{~d}, \mathrm{n}=4$ ) than in the later series $(4.34 \pm 0.15 \mathrm{~d}, \mathrm{n}=5)$ ( $t$-test, $\mathrm{df}=7, t=5.84, \mathrm{p}<0.001)$. The mean temperatures $( \pm \mathrm{SD})$ to which the transplanted eggs were subjected were significantly lower in the earlier series $\left(20.96 \pm 1.86^{\circ} \mathrm{C}, \mathrm{n}=4\right)$ than in the later serjes $\left(25.13 \pm 1.04^{\circ} \mathrm{C}, \mathrm{n}=5\right)$ ( $t$-test, $\mathrm{df}=7$, $t=-4.29, p<0.01$ ) The estimated incubation periods were negatively correlated with the mean temperatures $(r=-0.94, n=9, p<0.0001)$.

Temperatures of the site regularly fluctuated during the incubation of eggs and were higher when the site was exposed during daytime low tides (Fig 5). The temperatures during the daytime low tides tended to be higher in the middle of the spawning season; the maximum temperatures were over $30^{\circ} \mathrm{C}$ in the 4 th and 5 th spawning series (Table 1). In contrast, during nighttime low tides or when the site was inundated, temperatures were relatively lower (Fig. 5). In general, the temperatures during nighttime low tides and water temperatures were higher later in the spawning season; the minimum temperature in each series tended to increase with the spawning season (Table 1), and the correlation was significant $(\mathrm{r}=0.87, \mathrm{n}=9, \mathrm{p}<0.01$ ). Variation in temperature within a day tended to be large in the earlier spawning series (Fig. 5). The range of temperature fluctuation in each series (difference between the maximum and minimum temperature) was largest around the $3 \mathrm{rd}$ and 4 th spawning series (Table 1).

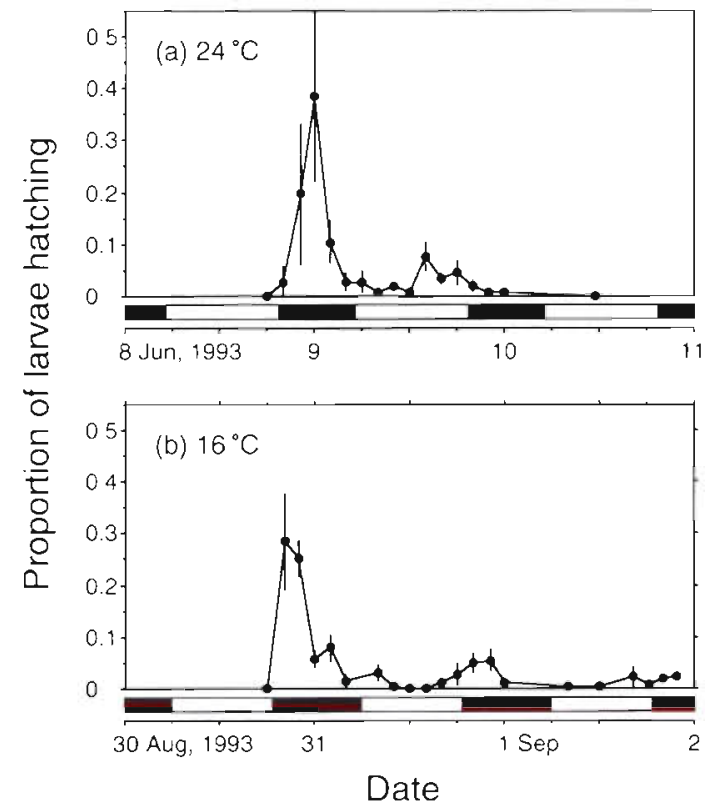

Fig. 4. Takifugu niphobles. Timing of hatching of larvae (mean proportion hatching $\pm \mathrm{SE}, n=5$ ) reared at (a) $24^{\circ} \mathrm{C}$ and (b) $16^{\circ} \mathrm{C}$ in the laboratory. Black and white bars indicate night and day, respectively

The relationship between the zone of stranded eggs and the tidal pattern at the spawning site indicated that in the earlier spawning series spawning occurred on days when the tidal amplitude was increasing (Fig. 6). On the other hand, in the later series, spawning tended to occur on days when the tidal amplitude was decreasing. The upper end of the zone of stranded eggs continued to be submerged by nighttime high tides for significantly more days in the earlier spawning series (mean $\pm \mathrm{SD}=7.58 \pm 3.60 \mathrm{~d}, \mathrm{n}=12$ ) than the later series $(5.07 \pm 2.06 \mathrm{~d}, \mathrm{n}=14)(t$-test, $\mathrm{df}=24, t=$ $2.22, \mathrm{p}<0.05)$. For 17 of the 26 spawning days $(65.4 \%)$, the number of days when the nighttime high tides continued to reach the upper end of the zone of stranded eggs was nearly equal to (the difference is less than 1 d) or longer than the estimated incubation periods (see also Table 1). For the remaining 9 days (34.6\%),

Table 1. Estimated incubation periods of embryos in each spawning series in 1993. Nest temperatures were recorded almost every hour during each incubation (see text for detall); mean, maximum, and minimum temperatures, and temperature ranges (difference between maximum and minimum temperature) during each incubation are also shown

\begin{tabular}{|c|c|c|c|c|c|c|c|c|c|}
\hline & \multicolumn{4}{|c|}{ ___Earlier spawning senes } & \multirow[b]{2}{*}{5 th } & \multicolumn{3}{|c|}{ - Later spawning series - } & \multirow[b]{2}{*}{9 th } \\
\hline & $1 \mathrm{st}$ & $2 n d^{2}$ & $3 r d$ & 4 th & & 6 th & 7 th & $8 \mathrm{th}$ & \\
\hline Incubation period (d) & 6.8 & 7.0 & 6.3 & 5.3 & 4.2 & 4.5 & 4.5 & 4.3 & 4.2 \\
\hline Mean temperature $\left({ }^{\circ} \mathrm{C}\right)$ & 18.9 & 19.9 & 22.1 & 23.0 & 26.5 & 24.6 & 25.6 & 25.0 & 23.8 \\
\hline Maximum temperature $\left({ }^{\circ} \mathrm{C}\right)$ & 24.9 & 26.8 & 29.4 & 30.9 & 32.4 & 28.9 & 291 & 28.6 & 28.5 \\
\hline Minimum temperature $\left({ }^{\circ} \mathrm{C}\right)$ & 16.1 & 177 & 176 & 19.2 & 22.9 & 21.5 & 23.9 & 23.6 & 21.6 \\
\hline Temperature range $\left({ }^{\circ} \mathrm{C}\right)$ & 8.8 & 9.1 & 11.8 & 11.7 & 9.5 & 7.4 & 5.2 & 5.0 & 6.9 \\
\hline
\end{tabular}


Earlier series

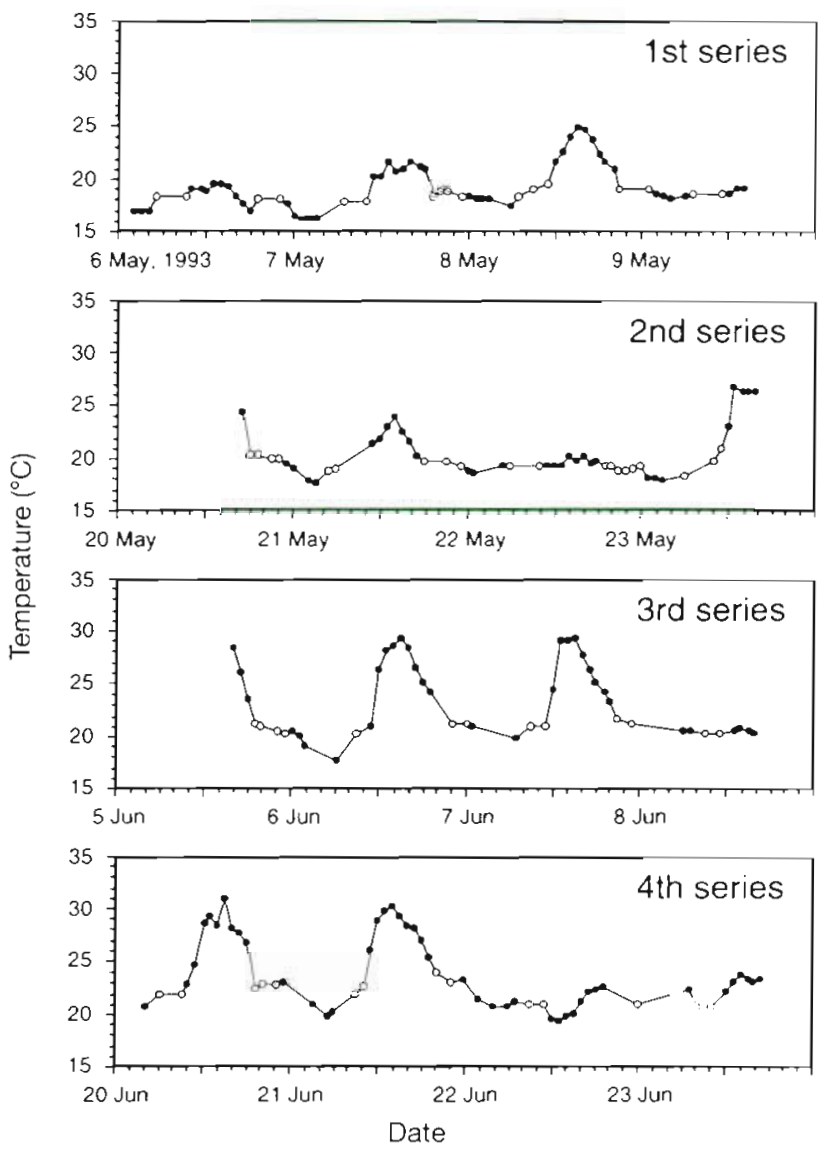

Fig. 5. Daily change in temperature of the site during the incubations of eggs in the field. (•) Temperature under pebbles during exposed periods; $(0)$ water temperature during submerged periods

however, the former was more than $1 \mathrm{~d}$ shorter than the latter. In particular, the differences were more than $2 \mathrm{~d}$ in the 1 st and $3 \mathrm{rd}$ spawning series.

\section{DISCUSSION}

\section{Egg survival during incubation}

After being released in the upper intertidal. zone, eggs of Takifugu niphobles are stranded under pebbles, where they incubate (Yamahira 1996). However, many died during the intertidal incubation (Fig. 2), especially early in the season. It has been reported that extreme temperatures reduce survival of embryos in the puffer (Yamahira 1996) and in other intertidal spawners, e.g. the Atlantic silverside Menidia menidia
Later series
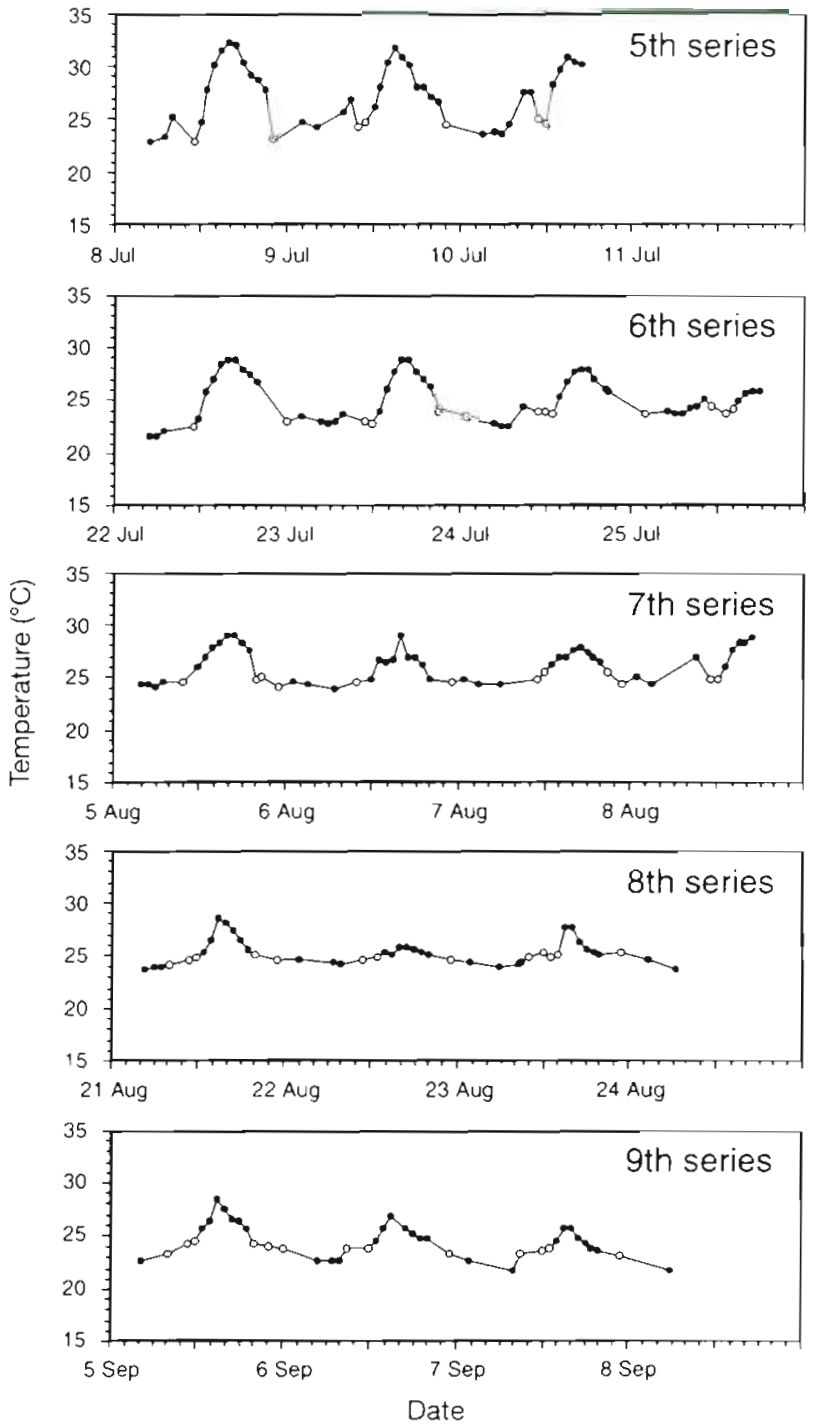

(Hutchinson 1961, Middaugh et al. 1983), the California grunion Leuresthes tenuis (Hubbs 1965, Ehrlich \& Farris 1971), and the Pacific herring Clupea harengus pallasi (Alderdice \& Hourston 1985, Purcell et al. 1990) In the present study, however, mean egg survival within each series was not significantly correlated with either the mean $(r=0.14, n=9, p=0.74)$ or: maximum $(r=-0.49, n=9, p=0.19)$ temperature in each series. In contrast, there was a significant negative correlation between the mean survival and the range of temperature fluctuation (difference between the maximum and minimum temperature) $(r=-0.82$, $n=9, p<0.01)$. This suggests that abrupt changes in temperature may be harmful to developing eggs. It has also been proposed that air-water temperature differentials are one of the primary mortality factors in the Pacific herring eggs deposited in the intertidal zone 


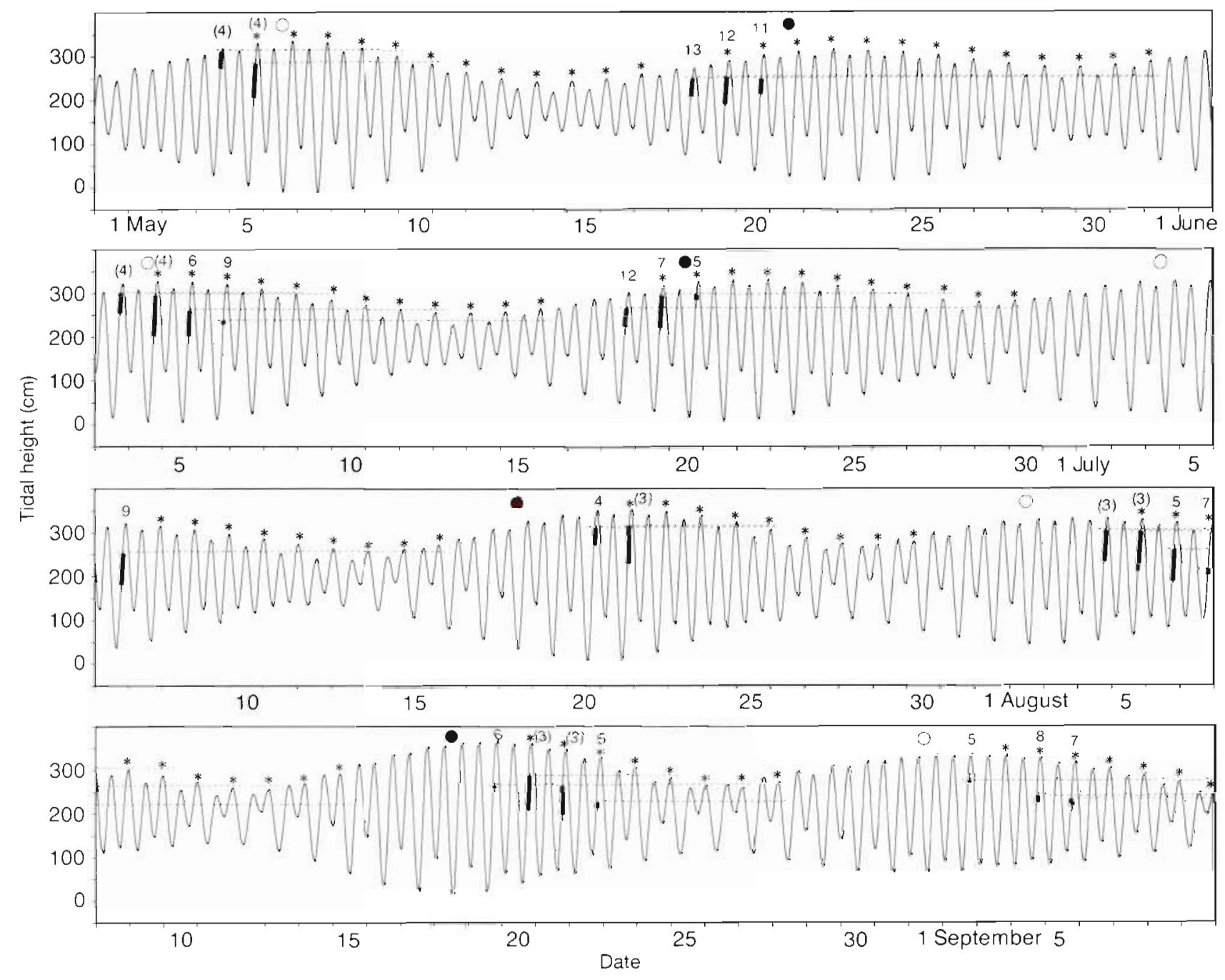

Fig. 6. Takifugu nuphobles. Relationship between the zone of stranded eggs and the tidal pattern at the site in 1993. Solid line shows the tidal curve of the site. Black bars show the zone of stranded eggs. "Nighttime (from sunset to sunrise) high tide. Dotted lınes: upper end of the zone of stranded eggs in each spawning day. Numbers over each spawning day indicate the number of days when nighttime high tides contınued to reach the upper end of the zone of stranded eggs, and numbers in parentheses indicate that the numbers of submerged days are more than $1 \mathrm{~d}$ shorter than the estimated incubation periods in each spawning series. Open and filled circles indicate full and new moons, respectively

(Jones 1972). Although high temperatures and/or large temperature fluctuations seem to be the primary causes of the puffer's embryo mortality during incubation in the field, other physical factors such as desiccation, hypoxia, or concentrated salinity might affect the survival simultaneously, as proposed in the other intertidal fishes (e.g. Jones 1972, Alderdice \& Hourston 1985).

\section{Timing of a day's hatch and incubation period of eggs}

In the present study, it was found that eggs in the field hatched out only during nighttime high tides (Fig. 3). It is unlikely that the larvae caught in this zone originated from offshore with the rising tide, because they would also have been caught in the lower zones during or just before the nighttime high tide. Even if eggs were reared being completely submerged in aerated seawater held at a constant temperature, larvae tended to hatch out during the dark under a cycle of light and darkness consistent with the natural diurnal cycle (Fig. 4). This suggests that the timing of hatching is related to the diurnal cycle and has a nocturnal peak. Although the effect of temperature or tidal fluctuations on the timing of hatching was not clear in this experiment, since submergence of the stranded eggs is essential for their hatching, the larvae are considered to hatch out only during submerged periods of dark, that is, during nighttime high tides. 
Because high tides occur twice a day around the site (i.e. semidiurnal tidal regime, see Barnwell 1976), one of them necessarily occurs during darkness. It has been reported that larvae of demersal marine spawners generally hatch out during darkness, especially at dusk (Thresher 1984, Gladstone \& Westoby 1988). It is assumed that nocturnal hatching is adaptive because the activities of visual predators on the larvae would be lowest during the dark hours of the day (e.g. Allen 1972, Johannes 1978, Lobel 1978). However, it is necessary to verify whether the larvae of Takifugu niphobles also gain the same advantage.

As the spawning season progressed, incubation period tended to be shorter This is because ambient temperatures at the site became progressively higher. The strong relationship between incubation time and ambient temperatures in fishes has been reported previously (e.g. Peterson et al. 1977, Alderdice \& Velsen 1978).

\section{Can the stranded eggs return to the sea? The hatching mechanism}

Since the incubation periods in the field were estimated at $7 \mathrm{~d}$ at most (Table 1), it appears that hatching occurred before the next spring tide. For successful hatching, however, the nighttime high tide of the estimated hatching day has to reach the eggs stranded in the upper intertidal zone.

Nighttime high tides reach the whole zone of stranded eggs for fewer days later in the season, because spawning tended to start after the day of the new or full moon when tidal amplitude continued to decrease. However, the estimated incubation periods of the eggs until hatching also became shorter as the season progressed. As a result, the incubation periods were nearly equal to or shorter than the periods during which the nighttime high tides continued to reach the upper end of the zone of stranded eggs for 17 of the 26 spawning days (Fig. 6). In other words, the eggs would continue to be submerged by the nighttime high tides at least until hatching, and they could hatch out successfully for the greater part of the season.

For the remaining 9 days, however, the incubation periods exceeded the number of days when nighttime high tides reached the upper ends of the zone of stranded eggs. Thus, some eggs would not have been submerged by tides and thus would not have hatched out, although. they would have developed fully and would have been ready to hatch. However, it appears that there were not many such eggs, because mating occurred very infrequently near the upper end of the spawning zone (Yamahira 1994). Taking account of the above fact and substantial errors involved in the vari- ous estimates, it is expected that most of the stranded eggs, even those deposited on the above 9 spawning days, were submerged and hatched out successfully. However, this may not have been the case for the 1st and $3 r d$ series when the incubation periods were more than $2 \mathrm{~d}$ longer than the periods of submergence

\section{Why is there a progressive shift in spawning from before to after the lunar syzygies? \\ Factors that determine the pattern of spawning within each spring tide}

Spawning does take place earlier in the semilunar cycle earlier in the season, and it seems to be adaptive because it allows more eggs, which need longer incubation periods earlier in the season, to hatch out successfully. If the eggs were released after the lunar syzygies in the earlier series, the incubation periods would considerably exceed the period during which nighttime high tides continue to reach the stranded eggs. This would result in the greater part of the stranded eggs being submerged only for the first few days. Such eggs would die before the next spring tide would wash them out. Therefore, spawning occurs prior to peak spring tides (dates of new and full moons) early in the season to allow sufficient time for completion of embryological development prior to the occurrence of neap tides, which may not flood the intertidal spawning site.

Why does spawning never occur on days before the new or full moon later in the season? This is probably related to egg survival during incubation. Egg survival is considered to be affected by the time of day during which the eggs are exposed, which is determined by the combination of phase in the diurnal and tidal cycles around this site (Yamahira 1996). Since low tides before the peak spring tides occur at midday, temperatures in the exposed intertidal zone would be too high to allow survival of the embryos, in particular, later in the season (July to August). Consequently, the most advantageous time for embryo survival is after the peak spring tides when the intertidal zone is inundated at midday and temperatures are moderated by the water cover Embryological development is faster at this time because of generally higher temperatures, and so there is ample time to complete development before entering the neap tide portion of the cycle

It should be noted that 2 competing selective pressures are acting on determining the pattern of spawning within each spring tide: spawning should shift later to maximize embryo survival during intertidal incubation, and earlier to maximize hatching success during periods of submergence. It appears that the relative intensity between the 2 selective pressures varies as 
the season progresses. In the earlier season when ambient temperatures are lower, more attention has to be paid to successful hatching than embryo survival during incubation because embryos need longer incubation periods to complete development. On the other hand, the relative importances of successful hatching and embryo survival are reversed later in the season, when ambient temperatures are higher. As a result, to maximize the number of living larvae transported offshore, the timing of spawning events would shift from before to after the new or full moon as the season progressed. Only from the viewpoint of the successful hatching, the puffer should have spawned several days earlier than they did in the 1st and 3rd spawning series, both of which belong to the earlier series, because the incubation periods far exceeded the periods during which nighttime high tides continued to reach the stranded eggs. However, by considering the viewpoint of maximization of embryo survival during incubation, the actual spawning days in these 2 series appear to have been the optimal time.

In conclusion, the number of larvae successfully hatched is provided by 2 components: embryo survival during intertidal incubation and successful hatch during periods of submergence. The progressive shift in the timing of spawning is the result of a seasonal tradeoff between the embryo survival and successful hatching which ultimately maximizes the success of larval dispersal. The mechanism by which the tish shift the timing of spawning events is unknown. As the season progresses, some physical (or chemical) conditions, such as water temperature, tidal amplitudes of each of new and full moon spring tides, progressively vary. Thus, one or some of these may be used as the environmental cues that drive the shift in the timing of spawning.

The same shift in spawning behavior described here has been observed in the mummichog Fundulus heteroclitus, which spawns intertidally and concentrates its spawning effort early in the season to the days just before spring tides associated with the full moons, and just after the new moon spring tides later in the season (Kneib 1986). It is argued that the shift in spawning occurs also to allow stranded eggs to be inundated and successfully hatch: the mummichog shifts the timing of spawning events to compensate for a seasonal difference in amplitudes of new versus full moon spring tides. Such seasonal shifts in timing of spawning in relation to successful hatching might be a characteristic common to many intertidal spawners which spawn in synchrony with lunar and tidal cycles such that eggs are deposited in the upper portion of the intertidal zone, e.g. the Atlantic silverside Menidia menidia (Middaugh 1981) and the California grunion Leuresthes tenuis (Walker 1952, 1959).
Some of the intertidal spawners with a high degree of specificity in the spawning elevation above mean low water are known to have a capacity for dulayed hatching (Walker 1952, 1959, Taylor et al. 1977. DiMichele \& Taylor 1980) In the case of Leuresthes tenuis, eggs usually remain out of water for about $10 \mathrm{~d}$, and hatching occurs when high tides of the next series of spring tides flood the stranded eggs. In addition, if the high tides fail to reach the eggs, some can remain alive for another 2 wk (Walker 1952, 1959). Eggs of Fundulus heteroclitus also sometimes delay hatching for up to a week until the spring tides following those on which they were spawned (Taylor et al. 1977). In contrast, eggs of the puffer Takifugu niphobles cannot remain alive out of water until the next spring tidal phase. This was demonstrated by the fact that no eggs were observed in the spawning site a few days before each spawning series began (author's pers. obs.). If eggs of the puffer, like those of $L$. tenuis and F. heteroclitus, were able to tolerate extended periods of exposure, the progressive shift in the timing of spawning, as described in the present study, would not have been observed because the eggs wouldn't have to hatch within the lunar phase in which they were released. In addition, in the puffer populations that use sandy beaches or rocky ones as spawning sites, where eggs are washed out seaward and incubated in the lower intertidal or subtidal zones (Nozaki et al. 1976. Honma et al. 1980), it is expected that the shift in spawning would not be observed because no attention would have to be paid to the tidal regime.

Acknowledgements This study was partially supported by JSPS Research Fellowships for Young Scientists (1150) and a Grant-in-aid for Scientific Research from the Ministry of Education, Science and Culture, Japan (1150). I would like to thank Prof T Kikuchi for siving me the opportunity to undertake this project. I also thunk Dr R. N Gibson, Dr S. J. Northcott, Dr Y Takada, Dr J. A. Raymond and the 4 anonymous referees for their helptul comments on the manuscript. I wish to dedicate this study to my wife Kyoko Yamahira for the field assistance and her continued encouragement This is contr1bution No. 407 from the Amakusa Marine Bıological Laboratory, Kyushu University.

\section{LITERATURE CITED}

Alderdice DF, Hourston AS (1985) Factors influencing development and survival of Pacific herring (Clupea harengus pallasi) eggs and larvae to beginning of exogenous feeding. Can J Fish Aquat Sci 42 (Suppl 1):56-68

Alderdice DF, Velsen FPJ (1978) Relation between temperature and incubation time for eggs of chinook salmon. J Fish Res Bd Can 35:69-75

Allen GR (1972) Anemonefishes. T.F.H. Publications, Neptune City, NJ

Barnwell FH (1976) Variation in the form of the tide and some problems it poses for biological timing systems. In: De 
Coursey PJ (ed) Blological rhythms in the manne environment. Univ South Carolina Press, Columbia, p 161-187

Berry AJ (1986) Semi-lunar and lunar spawning periodicity in some tropical littonnid gastropods. J Mollusc Stud 52: $144-149$

Christy J (1986) Timing of larval release by intertidal crabs on an exposed shore. Bull Mar Scs 39:176-191

DiMichele L, Taylor MH (1980) The environmental control of hatching in Fundulus heteroclitus. J Exp Zool 214:181-187

Dotsu Y, Nakamura H, Nishikawa Y, Maeda I (1990) Spawning behavior of the grass puffer, Takifugu niphobles, in the vicinity of Nagasaki. Nagasaki-ken Seibutsu Gakkaishi 36:7-15 (in Japanese with English abstract)

Ehrlich KF, Farns DA (1971) Some influences of temperature on the development of the grunion, Leuresthes tenuis (Ayres). Calif Fish Game 57:58-68

Gibson RN (1992) Tidally-synchronised behaviour in marine fishes. In: Ali MA (ed) Rhythms in fishes. Plenum Press, New York, p 63-81

Gladstone W, Westoby M (1988) Growth and reproduction in Canthigaster valentini (Pisces, Tetraodontidae): a comparison of a toxic reef fish with other reef fishes. Environ Biol Fish 21:207-221

Honma Y, Ozawa T, Chiba A (1980) Maturation and spawning behavior of the puffer, Fugu niphobles, occurring on the coast of Sado Island in the Sea of Japan (a preliminary report). Japan J Ichthyol 27:129-138

Hubbs C (1965) Developmental temperature tolerance and rates of four southern California fishes, Fundulus parvipinnis, Atherinops affinis, Leuresthes tenuis, and Hypsoblennuis sp. Calif Fish Game 51:113-122

Hutchinson VH (1961) Critical thermal maxima in salamanders. Physiol Zool 2:92-125

Japan Meteorological Agency (1992) Tidal tables for the year 1993. Japan Meteorological Agency, Tokyo

Johannes RE (1978) Reproductive strategies of coastal manne fishes in the tropics. Environ Biol Fish 3:65-84

Jones BC (1972) Effect of intertidal exposure on survival and embryonic development of Pacific herring spawn. J Fish Res Bd Can 29:1119-1124

Katayama M, Fujita S, Fujioka Y (1964) Ecological studies on the puffer, Fugu niphobles (Jordan et Snyder) I. On the spawning habit. Bull Fac Educ Yamaguchi Univ 13:35-44 (in Japanese)

Kneib RT (1986) Size-specific patterns in the reproductive cycle of the killitish, Fundulus heterocitus (PIsces: Fundulidae) from Sapelo Is]and, Georgia. Copeia 1986:342-351

Kornnga P (1947) Relations between the moon and the periodicity in the breeding of marine animals. Ecol Monogr 17 . $349-381$

Leatherland JF, Farbridge KJ, Boujard T (1992) Lunar and semi-lunar rhythms in fishes. In: Alı MA (ed) Rhythms in fishes. Plenum Press, New York, p 83-107

Lobel PS (1978) Diel, lunar, and seasonal periodicity in the

This article was submitted to the editor reproductive behavior of the pomacanthid Centropyge potteri and some reef fishes in Hawail. Pac Scl 32:193-207

Mictdaugh DP (1981) Reproductive ecology and spawning periodicity of the Atlantic silverside, Menidia menidia (Pisces: Athermidae). Copeia 1981:766-776

Middaugh DP, Kohl HW, Burnett LE (1983) Concurrent measurement of intertidal environmental variables and embryo survival for the California grunion, Leuresthes tenuis, and Atlantic silverside, Menidia menidia (Pisces: Athernidae). Calif Fish Game 69:89-96

Morgan SG (1995) The timing of larval release. In: McEdward $L$ (ed) The ecology of marine invertebrate larvae. CRC Press, Boca Raton, FL, p 157-191

Nozaki M. Tsutsumi $T$, Kobayashi $H$, Takeı $Y$, Ichikawa $T$, Tsuneki $K$, Miyagawa $K$, Uemura $H$, Tatsumi $Y$ (1976) Spawning habit of the puffer, Fugu niphobles (Jordan et Snyder) I. Zool Mag (Tokyo) 85:156-168 (in Japanese with English abstract)

Peterson RH, Spinney HCE, Sreedharan A (1977) Development of Atlantic salmon eggs and alevins under varied temperature regimes. J Fish Res Bd Can 34:31-43

Purcell JE, Grosse D, Grover JJ (1990) Mass abundances of abnormal Pacific herring larvae at a spawning ground in British Columbia. Trans Am Fish Soc 119:463-469

Robertson DR (1991) The role of adult biology in the tuming of spawning of tropical reef fishes. In: Sale PF (ed) The ecology of tishes on coral reets. Academic Press, San Diego, p 356-386

Suzuka M, Isogai S (1979) Spawning habit of the puffer, Fugu niphobles (Jordan et Snyder) at Koshigoe Beach of the Miura Peninsula. Sci Rep Yokosuka City Mus 24:57-66 (in Japanese with English abstract)

Taylor MH, DiMichele L, Leach GL (1977) Egg stranding in the life cycle of the mummichog. Fundulus heteroclitus. Copeia 1977:397-399

Thresher RE (1984) Reproduction in reef fishes. T.F.H. Publications, Neptune City, NJ

Tsutsumi T (1978) Spawning habits of the blowfish, Fugu niphobles. Heredity (Tokyol 32:73-79 (in Japanese)

Uno Y (1955) Spawning habit and early development of a puffer, Fugu (Toratugu) niphobles (Jordan et Snyder) J Tokyo Univ Fish 42:169-183

Walker BW (1952) A guide to the grunion. Callf Fish Game 38 $409-420$

Walker BW (1959) The timely grunion. Nat Hist 68:303-308

Yamahira $K$ (1994) Combined effects of tidal and diurnal cycles on spawning of the puffer, Takifugu niphobles (Tetraodontidae). Environ Biol Fish 40:255-261

Yamahira K (1996) The role of intertidal egg deposition on survival of the puffer. Takifugu niphobles (Jordan et. Snyder), embryos. J Exp Mar Biol Ecol 198:291-306

Yamahira K (1997) Proximate factors influencing spawning site specificity of the puffer fish Takifugu niphobles. Mar Ecol Prog Ser 147:1.1-19

Manuscript recelved: December 4, 1996

Revised version accepted: June 5, 1997 